\title{
PENTINGNYA MENINGKATKAN KINERJA PERAWAT DALAM \\ MENERAPKAN K3 DI RS
}

\author{
Dwi Syafriningsih
}

Email : dwisyafriningsih@gmail.com

\section{Latar Belakang}

Kinerja perawat merupakan prestasi kerja yang ditunjukkan oleh perawat dalam melaksanakan tugas-tugas asuhan keperawatan, sehingga menghasilkan kinerja yang baik bagi masyarakat, pasien dan perawat itu sendiri. Implementasi Patient Safety adalah setiap praktek yang mengurangi kemungkinan efek samping akibat paparan sistem perawatan kesehatan. Perawat yang berperan sebagai pemberi pelayanan dan mendampingi pasien 24 jam yang secara teratur berinteraksi dengan dokter, apoteker, keluarga dan tim kesehatan lain, berperan penting dalam memastikan keselamatan pasien dengan memantau kondisi pasien untuk mencegah terjadinya insiden, mendeteksi kesalahan dan nyaris cedera, memberikan pendidikan kesehatan dalam proses pemahaman perawatan dan melakukan tugas-tugas lain untuk memastikan pasien menerima perawatan yang berkualitas tinggi (Effken \& Abbott,
2009; "Nursing the Demands Of Quality, Patient Care," 2008).

Menurut pedoman Manjamen Kesehatan dan Keselamatan Kerja ( K3 ) di rumah sakit, Depkes ( 2006 ), dalam undang undang No 23 tahun 1992 tentang kesehatan pasal 23 dinyatakan bahwa upaya Kesehatan dan Keselamatan Kerja (K3) harus diselenggarakan disemua tempat kerja, khususnya tempat kerja yang mempunyai resiko bahaya kesehatan, mudah terjangkit penyakit atau mempunyai karyawan minimal 10 orang. Jika memperhatikan isi dari pasal tersebut, maka jelaslah bahwa rumah sakit termasuk kedalam kriteria tempat kerja dengan berbagai ancaman bahaya yang dapat menimbulkan dampak kesehatan, tidak hanya terhadap para pelaku langsung yang bekerja di rumah sakit, tapi juga terhadap pasien maupun pengunjung rumah sakit. Sehingga sudah seharusnyalah pihak pengelola rumah sakit menerapkan upaya 
Kesehatan dan Keselamatan Kerja ( K3 ) di Rumah Sakit.

Kesalahan yang mengakibatkan pasien cedera dapat berupa ketidaktepatan identifikasi pasien yang berakibat kesalahan atau keterlambatan diagnosis, kegagalan dalam bertindak, kesalahan pengobatan, dan kesalahan dosis atau metode dalam pemberian obat. Sasaran keselamatan pasien lainnya yang perlu diperhatikan untuk menghindari cedera pada pasien berupa peningkatan keamanan obat yang perlu diwaspadai, pengurangan resiko infeksi terkait pelayanan kesehatan, dan pengurangan resiko jatuh (Leape, et al, 1993, dalam Kohn, Corrigan, \& Donaldson, 2000, p.36).

\section{Metode}

Metode dalam penulisan ini menggunakan metode kualitatif, yaitu merupakan metode yang sifatnya memberikan suatu penjelasan dengan analisis. Metode ini bersifat subjektif, yaitu proses penelitian yang lebih fokus pada landasan teori. Metode yang digunakan dalam kajian ini adalah Literature review. Metode ini menganalisis, eksplorasi dan kajian bebas pada artikel, jurnal, maupun ebook yang releven dan berfokus pada metode pembelajaran klinik yang mempengaruhi kemampuan mahasiswa menerapkan k3. Adapun artikel yang digunakan pada literature review ini adalah artikel yang didapatkan dengan memuat 3 database Pubmed, Geogle Scholar dan Science Direct.

\section{Hasil}

Berdasarkan hasil pencarian literature didapatkan bahwa dengan meningkatkan kinerja perawat dapat meningkatkan kemampuan mahasiswa untuk lebih kritis dalam menerapkan k3 dalam melakukan tindakan. Keselamatan dan kesehatan kerja merupakan hal yang penting, karena dampak kecelakaan dan penyakit kerja tidak hanya merugikan perawat, tetapi juga rumah sakit baik secara langsung maupun tidak langsung. Keselamatan kerja berarti proses merencanakan dan mengendalikan situasi yang berpotensi menimbulkan kecelakaan kerja melalui persiapan prosedur operasi standar yang menjadi acuan dalam bekerja (Rika Ampuh Hadiguna, 2009).

Dari hasil pencarian atau analisis jurnal menunjukkan keselamatan dan kesehatan kerja memiliki pengaruh yang signifikan terhadap kinerja perawat. Hal ini menunjukkan bahwa K3 berperan penting dalam meningkatkan kinerja perawat karena 
K3 yang memberikan rasa nyaman dalam bekerja dan kepercayaan yang tinggi akan mendorong peningkatan perilaku kerja melalui jaminan.

Faktor yang mempengaruhi tingkat pengetahuan $\mathrm{k} 3$ berdasarkan hasil pencarian literature atau analisis jurnal. Yang pertama adalah pendidikan, sebanyak $94 \%$ pendidikan D-III, Hal ini menunjukkan bahwa pendidikan yang tinggi dapat meningkatkan pengetahuan seseorang. Oleh sebab itu, semakin tinggi pendidikan seseorang, pengetahuan yang dimilikinya akan semakin baik. Lalu yang kedua adalah lama nya bekerja atau pengalaman bekerja, sebanyak $87 \%$ Lama kerja kurang dari enam bulan memiliki risiko lebih tinggi untuk mengalami kecelakaan kerja, maka dari itu lama kerja secara tidak langsung dapat meningkatkan pengetahuan seseorang melalui pengalaman yang telah dialaminya selama ia bekerja. Hasil menunjukkan bahwa pihak manajemen rumah sakit telah memberikan dukungan dan upaya dalam terciptanya penerapan K3 yang baik dengan mengadakan pelatihan K3 berkala tiap tahunnya.

Penerapan merupakan proses untuk mempraktikan sesuatu yang dipengaruhi oleh faktor internal dan faktor eksternal.
Menurut WHO seseorang dapat berperilaku tertentu adalah upaya untuk menerapkan K3 terdapat 4 alasan pokok, yaitu pengetahuan, persepsi, sikap, dan kepercayaan. Meskipun pengetahuan K3 masih tergolong cukup, tetapi 3 alasan pokok lainnya mampu menunjang untuk menerapkan K3 dengan baik hingga dihasilkannya penerapan K3 yang baik.

\section{Pembahasan}

Kesehatan dan Keselamatan Kerja (K3) merupakan suatu upaya perlindungan kepada tenaga kerja dan orang lain yang memasuki tempat kerja agar terhindar dari bahaya akibat kecelakaan kerja. Tujuan K3 adalah mencegah, megurangi, bahkan menghilangkan resiko penyakit dan kecelakaan akibat kerja (KAK) dan juga meningkatkan kesehatan para pekerja sehingga kinerja perawat meningkat.

Kinerja merupakan tingkat keberhasilan seseorang secara keseluruhan dalam periode tertentu didalam melaksanakan tugas dibanding dengan berbagai kemungkinan seperti standart hasil kerja, target, sasaran atau kriteria yang telah ditentukan terlebih dahulu dan telah disepakati bersama. Hal ini dapat tercapai apabila rumah sakit selalu memperhatikan faktor keselamatan dan kesehatan kerja (K3) karena hal ini akan 
dapat meningkatkan kinerja perawat. Perhatian terhadap kesehatan pekerjaan pada mulanya lebih menekankan pada masalah keselamatan kerja yaitu perlindungan pekerjaan dari kerugian atau luka yang disebabkan oleh kecelakaan berkaitan dengan kerja. Kemudian seiring dengan perkembangan zaman, rumah sakit mulai memperhatikan kesehatan pekerja dalam arti luas yaitu terbebasnya pekerjaan dari kesakitan fisik maupun psikis (Mondy dan Noe III, 2005).

\section{Dalam Undang-Undang Republik Indonesia Nomor 36 Tahun 2009 Tentang} Kesehatan, upaya kesehatan kerja ditunjukkan untuk melindungi pekerja agar hidup sehat dan terbebas dari gangguan kesehatan serta pengaruh buruk yang diakibatkan oleh pekerjaan sehingga sudah seharusnya pihak pengelola RS menerapkan upaya-upaya K3 di RS.

\section{Indikator Keselamatan dan Kesehatan Kerja (K3)}

Menurut (Dessler:1997), indicator kesehatan karyawan terdiri dari :

1. Keadaan dan Kondisi Karyawan

Keadaan dan kondisi karyawan adalah keadaan yang dialami oleh karyawan/perawat pada saat bekerja yang mendukung aktifitas dalam bekerja.

2. Lingkungan kerja

Lingkungan kerja adalah lingkungan yang lebih luas dari tempat kerja yang mendukung aktifitas karyawan/perawat dalam bekerja.

3. Perlindungan karyawan

Perlindungan karyawan merupakan fasilitas yang diberikan untuk menunjang kesejahteraan karyawan.

Menurut (Suma'ar:1986) adapun indicatorindikator keselamatan kerja meliputi :

4. Tempat kerja

Adalah merupakan lokasi dimana para karyawan melaksanakan aktifitas kerjanya.

5. Mesin dan peralatan

Adalah bagian dari kegiatan operasional dalam proses produksi yang biasanya berupa alat-alat berat dan ringan.

\section{Pengaruh pengetahuan terhadap kinerja perawat}

Pengetahuan perawat tentang keselamatan pasien dapat mendorong perawat untuk melakukan suatu tindakan sesuai SOP keselamatan pasien sehingga berdampak pada kinerja implementasi keselamatan pasien. Hal ini berpengaruh terhadap kemampuan untuk meningkatkan mutu melalui aspek keselamatan pasien 
dipengaruhi oleh faktor individu. Optimalisasi perkembangan individu perawat memerlukan upaya peningkatan pengetahuan dan ketrampilan khusus dalam lingkup keselamatan pasien (Ghosh \& Scott, 2007; Randell, Mitchell, Thompson, McCaughan, \& Dowding, 2009).

Penelitian menyebutkan bahwa pengetahuan dan keterampilan yang handal dan baik dibutuhkan seorang perawat agar mampu berinteraksi dan berkomunikasi dengan baik antara perawat dan pasien sehingga dapat melaksanakan tanggung jawabnya dengan baik. Fokus pelayanan saat ini adalah patient center care yang menuntut perawat berperan sebagai pemberi pelayanan langsung sebagai ujung tombak pelayanan, sehingga perawat dituntut harus memiliki pengetahuan yang cukup dalam memberikan penilaian respon paisen, mengatasi masalah dan pengambilan keputusan (Morag et al., 2012; Xie, Li, Swartz, \& DePriest, 2012).

Meningkatkan pengetahuan perawat untuk memperbaiki kinerja dapat dilakukan dengan beberapa cara yaitu dengan sosialisasi, pelatihan berkelanjutan, dan belajar ke jenjang pendidikan yang lebih tinggi. Melalui tindakan dan belajar, seseorang akan bertambah kepercayaan dirinya dan berani mengambil sikap terhadap sesuatu yang akhirnya akan mempengaruhi perilaku. Penelitian lain menunjukkan perawat yang dituntut mempunyai jiwa caring dalam memberikan asuhan keperawatan, dimana tahap pertama pada caring adalah knowing yang artinya berusaha memahami arti suatu kejadian dalam kehidupan klien, berfokus pada perawatan untuk klien, melakukan pengkajian secara cermat dan melibatkan diri dengan klien. Proses ini merupakan proses awal saat perawat berinteraksi dengan klien (Keenan, Yakel, Lopez, Tschannen, \& Ford, 2013; "Nursing the Demands Of Quality, Patient Care," 2008).

Pengetahuan yang cukup dapat menimbulkan kepercayaan diri seorang perawat sehingga mendorong perawat untuk berperan aktif dalam diskusi dengan tim kesehatan lain. Seringkali ide-ide muncul dalam perawatan klien karena dengan pengetahuannya dapat memberikan motivasi mampu berfikir kritis dan cepat mengambil keputusan, dalam mengatasi permasalahan pasien dan meminimalkan kesalahan.

Upaya penerapan K3 di rumah sakit menyangkut tenaga kerja, cara/metode kerja, alat kerja, proses kerja, dan lingkungan kerja yang meliputi peningkatan, pencegahan, pengobatan, dan pemulihan. Tenaga kesehatan yang sering berkontak langsung 
dengan pasien adalah perawat. Tingkat pengetahuan K3 perawat sangat penting dalam menjaga keselamatan pasien dan diri perawat itu sendiri sesuai dengan penelitian terdahulu bahwa didapatkannya hubungan bermakna antara tingkat pengetahuan perawat dengan tindakan keselamatan terhadap pasien. Hasil penelitian menunjukkan sebanyak $67 \%$ telah menerapkan K3 dengan baik. Penerapan yang baik pada mayoritas responden dipengaruhi oleh pengetahuan termasuk di dalamnya dukungan lingkungan dan regulasi yang diterapkan.

Untuk mampu menciptakan tingkat pelayanan yang berkualitas dibutuhkan perawat yang memiliki kemampuan dengan kualitas yang baik, untuk menarik dan menpertahankan tenaga kerja yang berkualitas dan merupakan kebutuhan prasyarat sukses bagi sebuah rumah sakit. Reputasi rumah sakit merupakan modal pokok yang mencerminkan pada kemampuan rumah sakit untuk memuaskan Keselamatan dan kesehatan kerja (K3) adalah suatu program yang dibuat sebagai upaya mencegah timbulnya kecelakaan akibat kerja dan penyakit serta tindakan antisipatif apabila terjadi kecelakaan dan penyakit kerja.
Memang tidaklah mudah menilai kinerja sebuah rumah sakit melalui indikator. Kinerja rumah sakit haruslah diwakilkan oleh indikator yang menggambarkan faktor sukses kunci rumah sakit yang dapat diukur. Proses untuk menyusun indikator kinerja adalah proses yang kompleks karena adanya kepentingan yang harus dipertimbangkan dan perlunya perhitungan secara kuantitatif (Doucette and Millin, 2011). Indikator kinerja rumah sakit diartikan sebagai indikator yang definisikan secara statistik atau bentuk informasi lain baik secara langsung ataupun tidak langsung yang merefleksikan pencapaian terhadap outcome yang diharapkan atau kualitas dari proses pencapaian hasil (AIHW, 2013).

Kesalahan yang mengakibatkan pasien cedera dapat berupa ketidaktepatan identifikasi pasien yang berakibat kesalahan atau keterlambatan diagnosis, kegagalan dalam bertindak, kesalahan pengobatan, dan kesalahan dosis atau metode dalam pemberian obat. Sasaran keselamatan pasien lainnya yang perlu diperhatikan untuk menghindari cedera pada pasien berupa peningkatan keamanan obat yang perlu diwaspadai, pengurangan resiko infeksi terkait pelayanan kesehatan, dan pengurangan resiko jatuh (Leape, et al, 1993, dalam Kohn, Corrigan, \& 
Donaldson, 2000, p.36). Upaya penerapan keselamatan pasien sangat tergantung dari pengetahuan perawat. Apabila perawat menerapkan keselamatan pasien didasari oleh pengetahuan yang memadai, maka perilaku keselamatan pasien oleh perawat tersebut akan bersifat baik. Seorang perawat dalam memberikan asuhan keperawatan harus memiliki pengetahuan yang benar, keterampilan, dan sikap untuk menangani kompleksitas perawatan kesehatan. Tanpa pengetahuan yang memadai, tenaga kesehatan termasuk perawat tidak bisa menerapkan dan mempertahankan budaya keselamatan pasien (Myers, 2012, p.164).

\section{Penutup}

\section{Kesimpulan}

Dalam meningkatkan kinerja perawat dibutuhkan pengetahuan yang luas dan memadai, agar upaya dalam melakukan tindakan tidak mengakibatkan resiko besar. Upaya dalam menerapkan keselamatan pasien dan keselamatan kerja dibutuhkan perawat dengan kualitas yang baik. K3 merupakan perlindungan kerja yang bertujuan untuk menghindari terjadinya kecelakaan kerja dan mengurangi resiko penyakit.

\section{Saran}

Mengingat pentingnya meningkatkan kinerja perawat dalam menerapkan $\mathrm{k} 3$ di rs, maka disarankan agar perawat memliki pengetahuan luas dan memadai, agar dapat menerapkan $\mathrm{k} 3$ dengan baik.

\section{Daftar Pustaka}

Anugraihini, C., \& Sahar, J. M. (2010). Kepatuhan Perawat Menerapkan Pedoman Patient Safety Berdasarkan Faktor Individu dan Organisasi. Jurnal Keperawatan Indonesia, 13(3), 139-144.

Arruum, D., Salbiah, \& Manik, M. (2015). Pengetahuan Tenaga Kesehatan Dalam Sasaran Keselamatan Pasien Di Rumah Sakit Sumatera Utara. Idea Nursing Journal, $6(2)$.

Cahyono, A. (2015). Hubungan Karakteristik dan Tingkat Pengetahuan Perawat Terhadap Pengelola Keselamatan Pasien di Rumah Sakit. Jurnal Ilmiah WIDYA, 3(2).

Cahyono, S. B. (2008). Membangun Budaya Keselamatan Pasien Dalam Praktik Kedokteran. Yogyakarta: Kanisius. 
Darliana, D. (2016). HUBUNGAN PENGETAHUAN PERAWAT DENGAN UPAYA PENERAPAN PATIENTSAFETY DI RUANG RAWAT INAP RUMAH SAKIT UMUM DAERAH DR. ZAINOEL ABIDIN BANDA ACEH. Idea Nursing Journal. ISSN : 2087-2879. 7(1). 61-69.

Hanifa, N.D. Respati, T. Susanti, Y. (2017).

Hubungan Pengetahuan dengan Upaya Penerapan K3 pada Perawat. Bandung Meeting on Global Medicine \& Health (BaMGMH). 1(1). 144-149.

Ivana, A. Widjasena, B. Jayanti, S. (2014). Analisa Komitmen Manajemen Rumah Sakit (RS) Terhadap Keselamatan Dan Kesehatan Kerja (K3) Pada RS Prima Medika Pemalang. Jurnal Kesehatan Masyarakat (ejournal). 2(1). 35-41.

Nurhidayanti, D. (2017). PENGARUH PELAKSANAAN KESELAMATAN DAN KESEHATAN KERJA (K3) TERHADAP KEPUASAN KERJA PERAWAT (Studi Kasus Rumah Sakit Umum Daerah (RSUD). JOM FISIP. 4(1). 1-10.

Rahman, H. (2017). PENGARUH KESEHATAN DAN KESELAMATAN KERJA, PELATIHAN DAN KERJA TIM TERHADAP KINERJA TENAGA MEDIS DI RUMAH SAKIT BUDI KEMULIAAN
BATAM. DIMENSI. ISSN: 2085-9996. 6(2). 323-340.

Simamora, R. H. (2018). Buku ajar keselamatan pasien melalui timbang terima pasien berbasis komunikasi efektif: SBAR. Medan: USUpress.

Simamora, R. H. (2019). Buku ajar pelaksanaan identifikasi pasien. Uwais Inspirasi Indonesia

Sukesi, I. Soeharto, S. Ahsan. (2015). ANALISIS FAKTOR YANG BERHUBUNGAN DENGAN KINERJA PERAWAT MELAKSANAKAN KESELAMATAN PASIEN. ejournal.umm.ac.id. P-ISSN: 2086-3071, EISSN: 2443-0900. 6(1). 34-42. 